\title{
Potassium: A Vital Macronutrient in Potato Production-A Review
}

\author{
Shahram Torabian ${ }^{1}$, Salar Farhangi-Abriz ${ }^{2} \mathbb{D}$, Ruijun Qin ${ }^{1, * \mathbb{D}}$, Christos Noulas ${ }^{3} \mathbb{D}$, Vidyasagar Sathuvalli ${ }^{1} \mathbb{D}$, \\ Brian Charlton ${ }^{4}$ and Dimitra A. Loka ${ }^{3}$ \\ 1 Hermiston Agricultural Research and Extension Center, Oregon State University, Hermiston, OR 97838, USA; \\ shahram.torabian@gmail.com (S.T.); vidyasagar@oregonstate.edu (V.S.) \\ 2 Department of Plant Eco-Physiology, Faculty of Agriculture, University of Tabriz, Tabriz 5166616471, Iran; \\ farhanghi@hotmail.com \\ 3 Institute of Industrial and Forage Crops, Hellenic Agricultural Organization "Demeter", \\ 41335 Larissa, Greece; noulaschristos@gmail.com (C.N.); dimloka@gmail.com (D.A.L.) \\ 4 Klamath Basin Research and Extension Center, Oregon State University, Klamath Falls, OR 97603, USA; \\ brian.a.charlton@oregonstate.edu \\ * Correspondence: ruijun.qin@oregonstate.edu
}

\section{check for}

updates

Citation: Torabian, S.;

Farhangi-Abriz, S.; Qin, R.; Noulas,

C.; Sathuvalli, V.; Charlton, B.; Loka,

D.A. Potassium: A Vital

Macronutrient in Potato

Production-A Review. Agronomy 2021, 11, 543. https://doi.org/

10.3390 /agronomy11030543

Academic Editors: Emerson F.

C. Souza, Carl J. Rosen and Rogério P. Soratto

Received: 6 January 2021

Accepted: 11 March 2021

Published: 13 March 2021

Publisher's Note: MDPI stays neutral with regard to jurisdictional claims in published maps and institutional affiliations.

Copyright: (c) 2021 by the authors. Licensee MDPI, Basel, Switzerland. This article is an open access article distributed under the terms and conditions of the Creative Commons Attribution (CC BY) license (https:/ / creativecommons.org/licenses/by/ $4.0 /$ )
Abstract: Potassium (K) is a primary macronutrient for overall plant growth, yield potential, product quality and stress resistance of crops. Potato (Solanum tuberosum L.) crops require a high amount of potassium to achieve the ideal yield and quality. Therefore, the determination of optimum $\mathrm{K}$ rate and efficient source for potato is necessary because $\mathrm{K}$ affects crop physiological processes, dry matter production, cooking, and processing requirements. Through modeling on the pooled data extracted from 62 studies, the highest tuber yields might be obtained at an exchangeable soil $\mathrm{K}$ level of $200 \mathrm{mg} \mathrm{kg}^{-1}$ approximately, dependent on soil $\mathrm{pH}$, texture, and organic matter. Through modeling on the data of 48 studies, it also revealed that application of potassium sulfate $\left(\mathrm{K}_{2} \mathrm{SO}_{4}\right)$ and potassium chloride $(\mathrm{KCl})$ at rates of $200 \mathrm{~kg} \mathrm{ha}^{-1}$ and potassium nitrate $\left(\mathrm{KNO}_{3}\right)$ at a rate of 100 $\mathrm{kg} \mathrm{ha}^{-1}$ might achieve the ideal yield, implying the importance of $\mathrm{K}$ sources in potato production. However, these values (either soil exchangeable K content, or fertilizer rates) might not be applicable in a specific growing environment for a specific potato variety. It seems that there is no discrimination among split, pre-plant or in-season application of $\mathrm{K}$, although pre-plant fertilization might be a trustworthy strategy for economic tuber yield. Owing to the luxury consumption of $\mathrm{K}$ by potato crop, a combination of factors, including soil exchangeable $\mathrm{K}$ level, petiole $\mathrm{K}$ concentration, crop removal amount, soil conditions, management practices, climatic conditions, and potato variety, should be considered in order to make rational $\mathrm{K}$ fertilizer recommendations.

Keywords: Solanum tuberosum L.; tuber yield; potassium chloride; potassium sulphate; application rate; exchangeable soil $\mathrm{K}$

\section{Introduction}

Potato (Solanum tuberosum L.) is a versatile vegetable with an overall production of almost 368 million tons [1]. More than 1 billion people world-wide consume potato; its prominence in agriculture follows cereals like rice, wheat, and maize [1]. Potato produces more edible energy in a shorter period than cereals, which makes it as one of the most essential non-grain foods in the world [2]. If potato is suitably fitted into a proper crop rotation system, it could result in specific achievements such as reduction of pests, weeds, and suppression of disease [3]. In addition to its value on the fresh market, potato is important in other food sectors, such as frozen forms, chips, dehydrated potato products, and potato starch, et al. [4]. Potato is a nutritious food consisting of about $77 \%$ water, $16.3 \%$ starch, $0.9 \%$ sugar, $4.4 \%$ protein, $0.9 \%$ minerals, $0.59 \%$ fiber, $0.14 \%$ crude fat, and a considerable source of vitamins $\mathrm{A}, \mathrm{B}$ and $\mathrm{C}$, and such minerals as potassium $(\mathrm{K})$, magnesium $(\mathrm{Mg})$ and iron $(\mathrm{Fe})[5-7]$. 
Yield and quality of potato tubers are influenced by many distinct factors such as genetics (cultivar peculiarities), soil fertility, weather conditions, and chemical treatments [8]. However, potato requires substantial nutrient inputs to maintain its productivity and to produce quality tubers. To ensure the quantity and quality of potato tubers, rational use of mineral fertilizers seems necessary [4]. Moreover, sufficient supply of essential elements may improve potato's ability to resist disease $[9,10]$. Thus, appropriate nutrient management is critical to achieve high potato tuber yield and quality [11]. The ability of the crop to synthesize considerable amounts of carbohydrates requires sufficient supply of various nutrients. Of the 13 essential plant macronutrients and trace elements, three of them: nitrogen $(\mathrm{N})$, phosphorus $(\mathrm{P})$ and $\mathrm{K}$, are the top elements that determine crop yields [11].

Potassium is required in large quantities for optimum plant growth and productivity, since it is essential for completion of various physiological and metabolic functions in plants [12]. As an osmoticum, K maintains cell growth and turgor pressure [12,13], hydraulic conductance [14], leaf expansion [15], root elongation [16], transport of photoassimilates between source and sink organs [17], and regulation of stomatal guard cells [18]. Additionally, by facilitating carbon dioxide $\left(\mathrm{CO}_{2}\right)$ diffusion through the leaf mesophyll, $\mathrm{K}$ plays a key role in photosynthesis $[19,20]$. In plant tissues, $\mathrm{K}$ is considered as the second most abundant nutrient after $\mathrm{N}$ and it is even more abundant than $\mathrm{P}$. $\mathrm{K}$ must be dissolved in water to be available to plants [21]. As a result, $\mathrm{K}$ losses might happen via leaching and soil surface run-off contributing to plant $\mathrm{K}$ deficiencies, so that even agricultural soils that are considered rich in $\mathrm{K}$ minerals, may be subject to soil $\mathrm{K}$ imbalances, and increase the demand for commercial $\mathrm{K}$ fertilizers [22].

The role of $\mathrm{K}$ in potato plant growth, in the biochemistry of starch synthesis, in tuber quantity and quality is well documented in the literature $[23,24] ; \mathrm{K}$ is a macronutrient that is taken up in large amounts by the crop [25]. Because of crop's high K requirement to gain a high yield of marketable tubers [24], K fertilizer application rates and sources must be based on plant biological requirements. Hence, the current review is aiming at providing timely information on $\mathrm{K}$ regime optimization for potato cultivation regarding source, method of application, application rate and timing.

\section{Soil K Availability and Its Effect on Potato Yield}

Soil K mainly exists as unavailable form, contained in the mineral feldspars and mica crystalline structures (96-99\%) [26]. The soil available K exists as three distinct fractions: (1) water-soluble $\mathrm{K}$, dissolved in the soil solution $(0.1-0.2 \%)$; (2) exchangeable $\mathrm{K}$, adsorbed to or released from the surfaces of clay particles and organic matter (1-2\%); (3) slowly available K, trapped between layers of clay particles, which is indicative of the soil's longterm ability to supply K [26]. These three forms exchanged each other. Both water-soluble $\mathrm{K}$ and exchangeable $\mathrm{K}$ are considered readily available forms for plant growth and are measured routinely in soil testing labs under the name of available K or exchangeable $\mathrm{K}$. The initial soil exchangeable $\mathrm{K}$ is the main source of $\mathrm{K}$ nutrition for crops. Soil studies reported that potato plants respond to applied $\mathrm{K}$ when the soil exchangeable $\mathrm{K}$ content is $<80-120 \mathrm{mg} \mathrm{kg}^{-1}[27,28]$. However, other studies have reported positive yield responses to $\mathrm{K}$ fertilization even at high soil available $\mathrm{K}$ levels (>300 $\mathrm{mg} \mathrm{kg}^{-1}$ ) [29].

Results by Grewal and Singh [30] indicated that for $\mathrm{K}$ fertilizer recommendations, the critical level of available $\mathrm{K}$ was $105-114 \mathrm{mg} \mathrm{kg}^{-1}$ or less in alluvial soil. Data taken from 34 experiments in volcanic soils of southern Chile showed that under no K fertilization, fresh tuber yield ranged between 18.5 and 66.0 ton ha $^{-1}$ [31]. Across all of the experiments, the relationship between relative tuber yield and initial soil exchangeable K content showed yield reductions when initial soil exchangeable $\mathrm{K}$ values were $<300 \mathrm{mg} \mathrm{kg}^{-1}$. Moreover, even in soils with high initial soil exchangeable $\mathrm{K}\left(>360 \mathrm{mg} \mathrm{kg}^{-1}\right)$, low tuber yields were observed under no $\mathrm{K}$ fertilization [31]. These results were attributed to rainfed experimental conditions, which shortened the crop cycle and lowered potato yield potential. 
Tuber yield responses to $\mathrm{K}$ fertilizers may be negative in soils with high exchangeable $\mathrm{K}$ content $\left(>250 \mathrm{mg} \mathrm{kg}^{-1}\right.$ ) [32,33]; while fertilization increases the number of tubers per plant and tuber yield under low (<150 mg kg-1) or medium (150-250 $\mathrm{mg} \mathrm{kg}^{-1}$ ) soil K availability [34-36]. Several studies indicated an increase in tuber yield with the application of $\mathrm{K}$ fertilizer, even when soil test $\mathrm{K}$ results were adequate $[33,37,38]$, which may be related to other factors such as growing season conditions, irrigation schemes, variety, and soil $\mathrm{pH}$. Potato yield was noticeably increased, due to application of $\mathrm{K}$, when the initial soil available $\mathrm{K}$ content was at $75 \mathrm{mg} \mathrm{kg}^{-1}$ [39]. In agreement with this study, Panique et al. [40] reported that under soil $\mathrm{K}$ content ranging between 75 and $110 \mathrm{mg} \mathrm{kg}^{-1}$, tuber yield increased, with $\mathrm{K}$ application, up to $332 \mathrm{~kg} \mathrm{ha}^{-1}$. Other studies reported no yield response to $\mathrm{K}$ fertilization when levels of soil available $\mathrm{K}$ were low $\left(86 \mathrm{mg} \mathrm{kg}^{-1}\right)$ [37], although the authors did not offer a specific reason for this outcome. In a three-year experiment, Shi et al. [41] found that optimum $\mathrm{K}$ fertilizer rates were higher when the initial exchangeable $\mathrm{K}$ level was lower. Specifically, at the initial exchangeable $\mathrm{K}$ level of $108 \mathrm{mg} \mathrm{kg}^{-1}$, the optimum $\mathrm{K}$ fertilization rate exceeded $240 \mathrm{~kg} \mathrm{~K}_{2} \mathrm{O} \mathrm{ha}^{-1}$. By contrast, when initial exchangeable $\mathrm{K}$ levels were 128-168 $\mathrm{mg} \mathrm{kg}^{-1}$, the optimum $\mathrm{K}$ rate was $>150 \mathrm{~kg} \mathrm{~K}_{2} \mathrm{O} \mathrm{ha}^{-1}$.

Several soil factors have been reported to affect soil exchangeable $\mathrm{K}$ levels as well as tuber yield, including soil $\mathrm{pH}$, texture, and organic matter content. In general, potato grows best in slightly acidic, well-drained and fertile soils. To understand correlations between soil exchangeable $\mathrm{K}$ and tuber yield as affected by these parameters, data from 62 studies were organized by soil $\mathrm{pH}$, organic matter content and soil texture (Figures 1-3, respectively) for analysis. Initially, the data were evaluated by Kolmogorov-Smirnov test in terms of normality. Abnormal data were converted with natural logarithm linearizes to provide more normal sampling distribution in the following analyzing process. Then, the polynomial regression model was used for analyzing the new data under each parameter. As illustrated in Figure 1, a similar pattern was observed for potato tuber yield under acidic $(\mathrm{pH}<6.5)$, neutral $(\mathrm{pH}=6.5-7.5)$ and alkaline $(\mathrm{pH}>7.5)$ soil conditions. The highest tuber yield ( $\sim 30$ ton ha ${ }^{-1}$ ) was recorded in a soil with $200 \mathrm{mg} \mathrm{kg}^{-1}$ soil exchangeable $\mathrm{K}$ under varying soil $\mathrm{pH}$; yield did not increase further above that level with increasing $\mathrm{K}$ content (Figure 1). When the exchangeable $\mathrm{K}$ increased further, a reduction trend of tuber yield was observed in all the soils and the trend was more distinct in acidic soil. The yield reduced due to excessive $\mathrm{K}$ levels is mainly associated with imbalanced nutrients. The antagonistic relationships between $\mathrm{K}$ and $\mathrm{N}, \mathrm{Mg}$, and $\mathrm{Ca}$ implies that the excessive level of $\mathrm{K}$ may result in the inefficient uptake of these nutrients [42]. On the other hand, the synergistic effects between $\mathrm{K}$ and some micro-nutrients (e.g., such as Fe and $\mathrm{Mn}$ ) might result in excessive uptake of these micronutrients [42]. This situation could be more serious in acidic soils due to toxic effect of micronutrients [34], $\mathrm{H}^{+}$, and $\mathrm{Al}^{3+}$.

Potato yields increased in soils with high organic matter content $(>2 \%)$ compared to moderate $(1-2 \%)$ or low $(<1 \%)$ content. Regardless of soil organic matter content, tuber yield was the highest in soils containing $200 \mathrm{mg} \mathrm{kg}^{-1}$ exchangeable $\mathrm{K}^{+}$(Figure 2). A reduction in tuber yield was observed as $\mathrm{K}$ content increased to $250 \mathrm{mg} \mathrm{kg}^{-1}$ in soils of varying organic matter content (Figure 2). As shown in Figure 3, irrespective of soil texture, potato tuber yields increased as soil exchangeable $\mathrm{K}^{+}$increased up to about $200 \mathrm{mg} \mathrm{kg}^{-1}$; however, beyond that level, yields declined in fine textured soils. Similarly, potato tuber yields declined in medium-textured and course-textured soils when the soil exchangeable $\mathrm{K}$ level rose above $250 \mathrm{mg} \mathrm{kg}^{-1}$. An understanding of the relationship between soil available $\mathrm{K}$ content and potato yield can be used to develop $\mathrm{K}$ fertilization guidelines for potato production practices. Figure 4 was based on logarithmic pooled data and demonstrates that maximum tuber yield coincides with a soil available $\mathrm{K}$ of $200 \mathrm{mg} \mathrm{kg}^{-1}$, whereas no considerable yield increase (and perhaps a yield decline) can result from soils with higher K contents. 

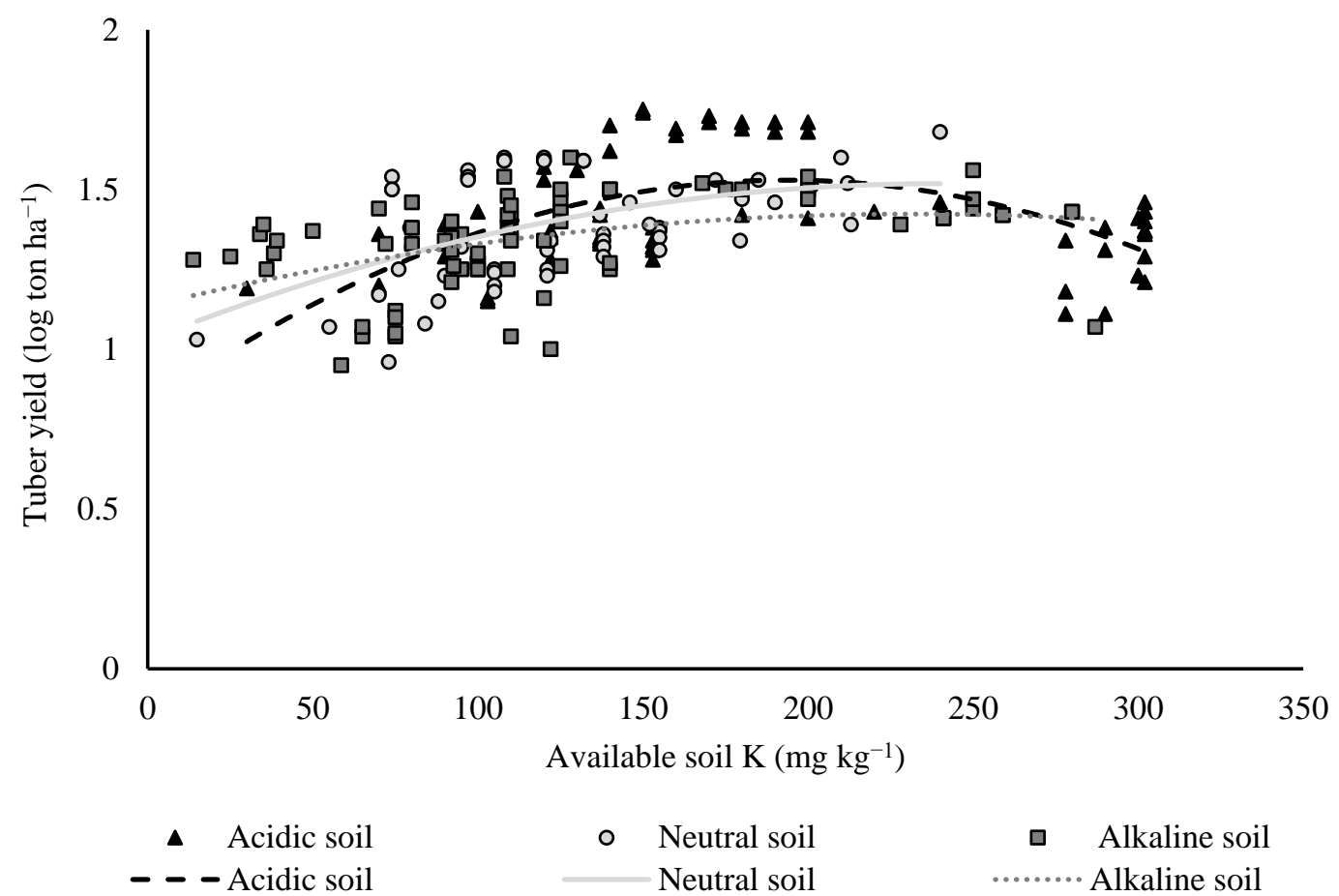
- Neutral soil Neutral soil

․ Alkaline soil . Alkaline soil

Figure 1. Changes in tuber yield of potato in response to exchangeable soil $\mathrm{K}^{+}$content in soils of varying $\mathrm{pH}$. Acidic soil: $\mathrm{pH}<6.5$; Neutral soil: $6.5 \leq \mathrm{pH} \leq 7.5$; Alkaline soil: $\mathrm{pH}>7.5$. (Some data used here are sourced from Supplementary Materials).

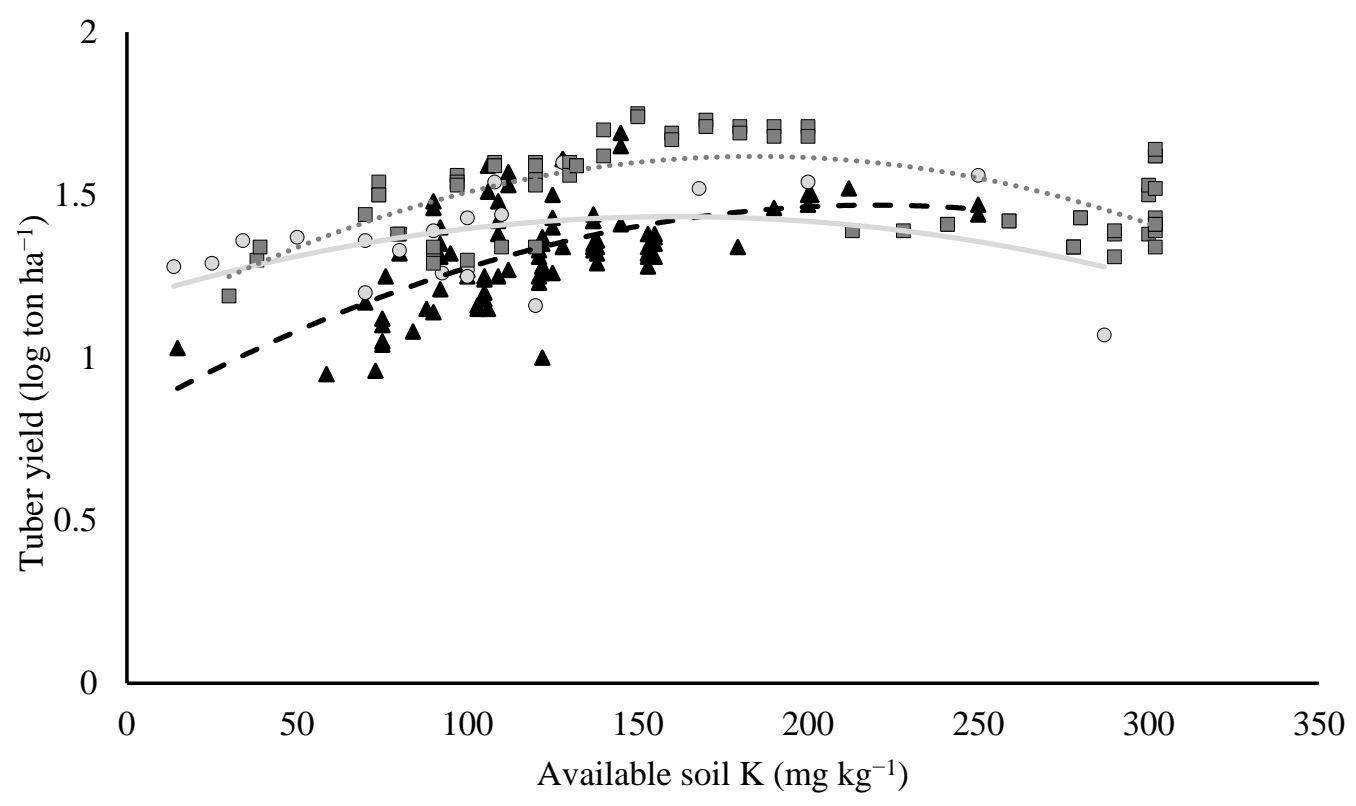

- Low organic matter

․ High organic matter

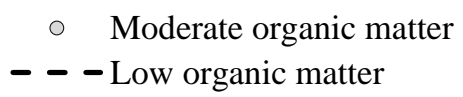

Figure 2. Changes in tuber yield of potato in response to exchangeable soil $\mathrm{K}^{+}$content in soils of varying organic matter content. Low organic matter: $\mathrm{OM}<1 \%$; Moderate organic matter: $1 \% \leq \mathrm{OM} \leq 2 \%$; High organic matter: OM $>2 \%$. (Some data used here are sourced from Supplementary Materials). 


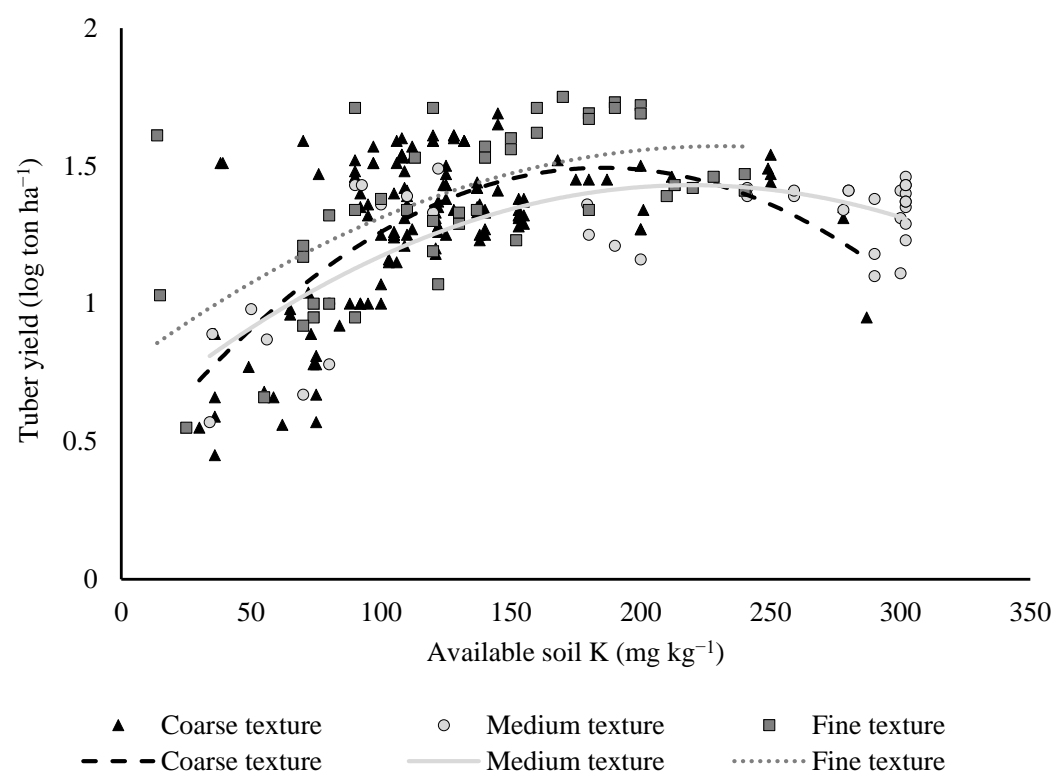

Figure 3. Changes in tuber yield of potato in response to exchangeable soil $\mathrm{K}^{+}$content in varying soil textures. Coarse: The predominant particle of soil is sand. Medium: The predominant particle of soil is silt; Fine: The predominant particle of soil is clay. (Some data used here are sourced from Supplementary Materials).

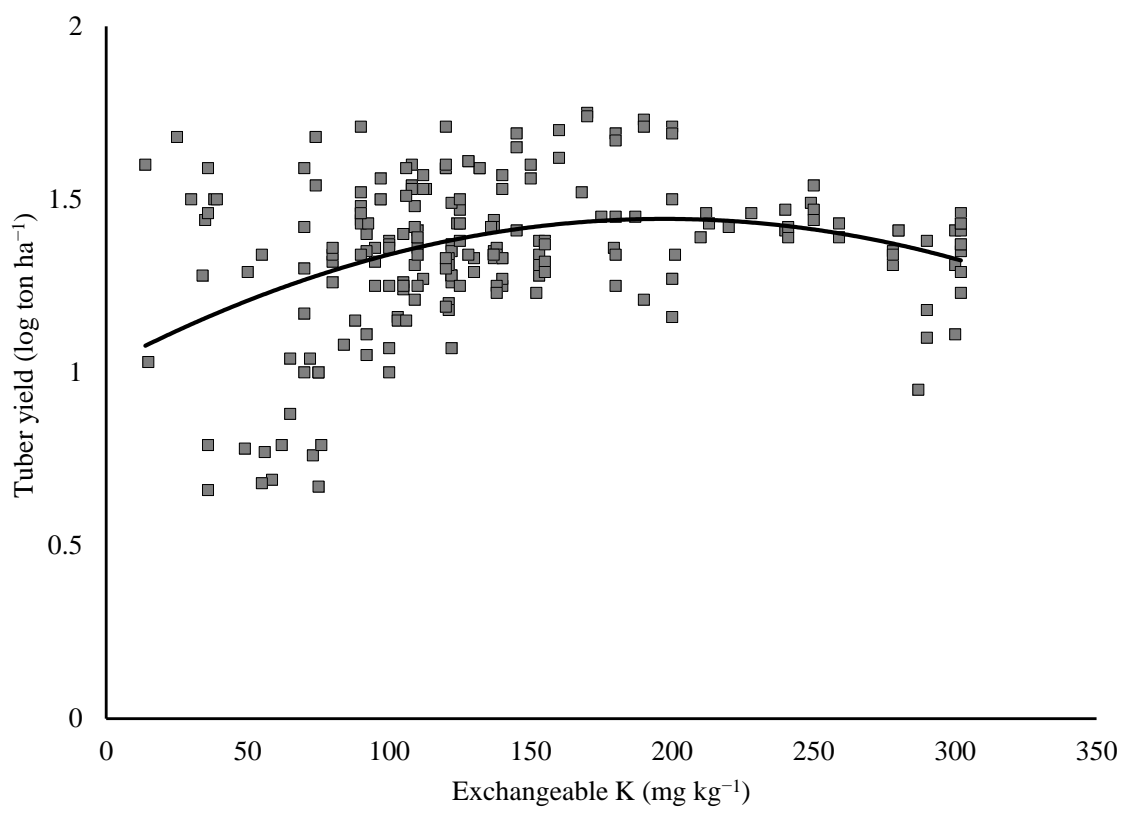

Figure 4. Changes in tuber yield of potato in response to exchangeable soil $\mathrm{K}^{+}$content. (Some data used here are sourced from Supplementary Materials).

\section{The Effect of K Application on Potato}

Optimal production requires considerable attention to the $\mathrm{K}$ requirement of potatoes. These requirements are large in comparison to cereals, pulses, oilseeds, and other commercial crops; however, potato produces considerably much more dry matter during a shorter growing cycle than some of these crops [25]. According to Bishwoyog and Swarnima [43], a yield of 30 tons of potato tubers removes $250 \mathrm{~kg} \mathrm{ha}^{-1} \mathrm{~K}$ from the soil. The concentration of $\mathrm{K}$ in potato is greater than any of the macronutrients, approximating $1.7 \%$ of dry matter [44]. Because of its importance in potato production, the effects of $\mathrm{K}$ application method on potato are discussed here in detail according to growth, tuber yield and quality parameters, while Table 1 summarizes $\mathrm{K}$ fertilizers effects (source, rate, and time) on growth and productivity of potato. 
Table 1. An overview of $\mathrm{K}$ fertilizers' effects on potato growth and productivity.

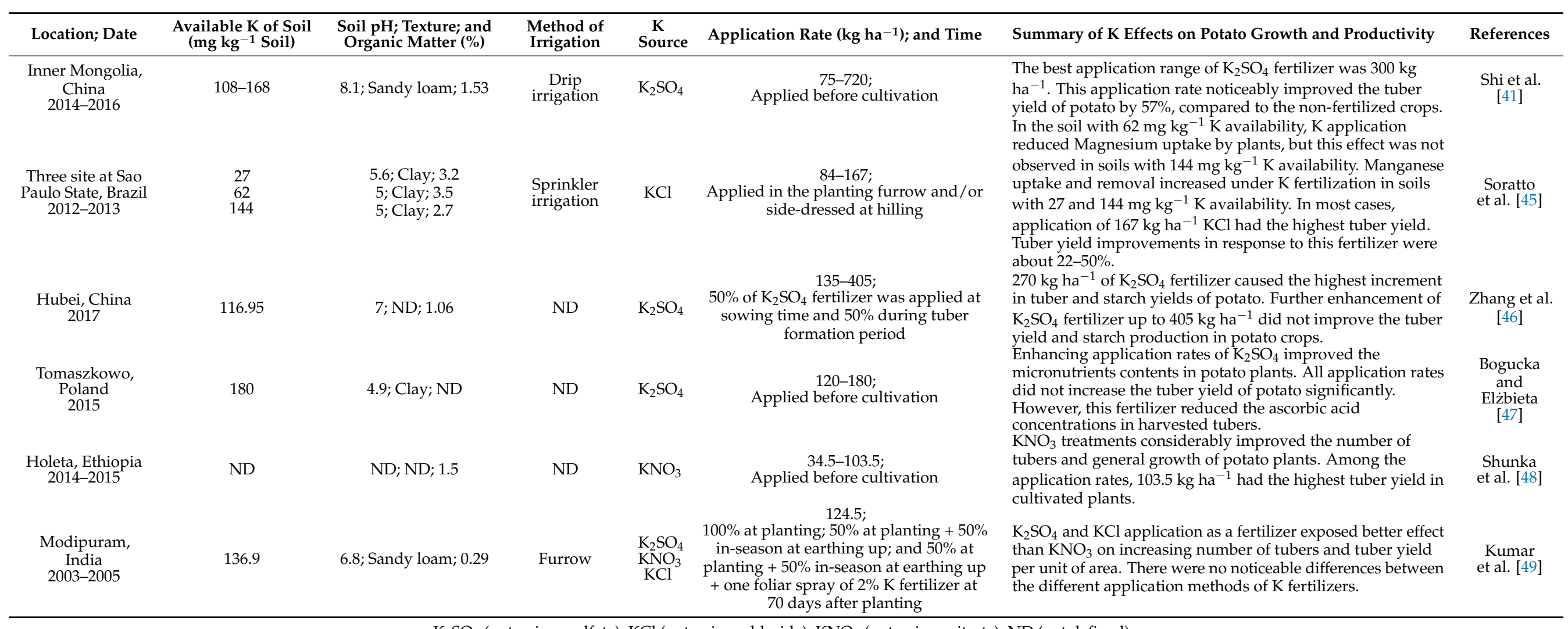

$\mathrm{K}_{2} \mathrm{SO}_{4}$ (potassium sulfate); $\mathrm{KCl}$ (potassium chloride); $\mathrm{KNO}_{3}$ (potassium nitrate); $\mathrm{ND}$ (not defined). 


\subsection{The Effect of K on Potato Growth and Tuber Yield}

Potassium has been shown to increase leaf expansion at early stages of growth and delay leaf shedding at maturity, and this has been attributed to its positive effect on enzyme activity, protein synthesis and translocation of assimilates [50]. Accordingly, Trehan et al. [51] stated that $\mathrm{K}$ application resulted in greater leaf area and increased plant height. In addition, higher $\mathrm{K}$ levels were observed to increase the height of potato crop, chlorophyll content in plants, leaf area, tuber $\mathrm{K}$ concentration and carbohydrates $[52,53]$. Several studies have shown that potato yield is considerably decreased under conditions of $\mathrm{K}$ deficiency $[23,52,54]$ and many researchers have recorded increases in potato tuber yield resulting from increases of $\mathrm{K}$ fertilization $[55,56]$. Potassium enhances the overall growth of the plants [46] and facilitates the translocation of assimilates to the tubers [38]. This could increase tuber bulking capacity, tuber biomass and yield. $\mathrm{K}$ increases the rate and the duration of tuber bulking. There are conflicting reports regarding the application of $\mathrm{K}$ fertilization to potato plants, particularly with respect to its effect on tuberization. Soil studies reported that higher tuber bulking rate over tuber bulking period resulted in higher yield at high fertility level [57], whereas other studies indicated zero or low crop response to high application rates of $\mathrm{K}[25,58]$.

\subsection{The Effects of K on Tuber Size}

Past research has indicated that elevated $\mathrm{K}$ application rates resulted in an increase in the yield of potato tubers weighing $<25 \mathrm{~g}$, while tubers weighing between 25 and $50 \mathrm{~g}$ and 51 and $75 \mathrm{~g}$ were not affected. Nevertheless, a non-significant effect of $\mathrm{K}$ on the yield of tubers weighing $<25 \mathrm{~g}$ has also been reported [59,60]. Furthermore, Tawfik [61] observed that under higher $\mathrm{K}$ rate, yield of $28-60 \mathrm{~mm}$ and $>60 \mathrm{~mm}$ diameter tubers of the cv. 'Spunta' grown in a sandy soil under drip-irrigation increased by $~ 15$ and $40 \%$, respectively. Adhikari and Karki [62] reported that an increase in tuber size requires maximum $\mathrm{K}\left(100 \mathrm{~kg} \mathrm{~K}_{2} \mathrm{O} \mathrm{ha}^{-1}\right)$. Due to the function of $\mathrm{K}$ in facilitating the translocation of assimilates from leaves to tubers, an increase in the volume of tuber and tuber size is expected [19,23,63]. According to Trehan [51], K activates a number of enzymes involved in photosynthesis, carbohydrate metabolism, protein synthesis, and assists in the translocation of carbohydrates from leaves to tubers, which increases the size of tubers but not their number. K nutrition increases the average size of the tuber significantly [38], which could be reflected in enhanced aggregate yield [64].

\subsection{The Effect of K on Tuber Quality}

Tuber quality includes external features, such as tuber size, shape, skin and flesh color, depth of eyes, greening and mechanical damage as well as internal features including dry matter content, growth cracks, hollow heart, and internal bruising. Potatoes are also evaluated for cooking quality factors, namely enzymatic and non-enzymatic browning, texture and flavor [65]. Farming practices, including plant density, irrigation and nutrient management, influence tuber quality [66]. Zörb et al. [67] indicated that $K$ is one of the most important nutrients affecting potato tuber quality. Potassium fertilization has a greater positive effect on tuber quality than on yield [68].

However, it seems that the effect of $\mathrm{K}$ fertilization on potato quality is contradictory. Some studies reported that $\mathrm{K}$ improved percentage dry matter and starch content by activating the starch synthase enzyme [69], while other studies reported that $\mathrm{K}$ fertilization decreased dry matter content [32,35], starch [25], protein [70], and total phenolics [53]. Additionally, Perrenoud [71] stated that despite improved starch synthesis and translocation, $\mathrm{K}$ could reduce overall dry matter percentage by increasing water content of tubers. Contradictory results were also recorded in terms of $\mathrm{K}$ application on specific gravity of potato tubers with some studies reporting reductions $[33,69]$, while no impact was observed in other studies [37,72]. Reduction in specific gravity is often associated with $\mathrm{KCl}$ application than other K sources due to greater K uptake, and a higher salt index, which increases water absorption by tubers [33]. 
The importance of $\mathrm{K}$ in potato quality can be attributed to its role in promoting photosynthesis and translocation of photosynthates, as well as enhancing of their conversion into starch and protein [73]. Hannan et al. [74] indicated that the concentrations of sugars were decreased, while tuber starch content was increased with increasing $\mathrm{K}$ application rates up to $237 \mathrm{~kg} \mathrm{ha}^{-1}$. Less sugar concentration (glucose + fructose) is an important factor for the processed potato industry, because sugars darken during frying and hence higher sweetening trait in tubers results in lower quality chips/fries [24,71]. The lighter color of chips/fries can also be due to the influence $\mathrm{K}$ has on lowering sugar and amino acids contents in potatoes, as elevated levels of these compounds can darken chips during frying [75]. It is believed that high rate of $\mathrm{K}$ fertilizer improves cooking and processing qualities, the color of the final fried product, and the starch quality [71]. Potassium also improves storage quality and shelf life of potato since it may reduce blackspot bruising severity of tubers [76]. Table 2 summarizes the effects of different sources and rates of $\mathrm{K}$ application on tuber quality. 
Table 2. An overview of $\mathrm{K}$ fertilizers effects on potato tuber quality.

\begin{tabular}{|c|c|c|c|c|c|c|}
\hline Location; Date & $\begin{array}{l}\text { Available K of Soil } \\
\text { (mg kg } \text { }^{-1} \text { Soil) }\end{array}$ & $\begin{array}{l}\text { Soil } \mathrm{pH}_{;} \text {Texture; and } \\
\text { Organic Matter }(\%)\end{array}$ & K Source & $\begin{array}{c}\text { Application Rate }\left(\mathrm{kg} \mathrm{ha}^{-1}\right) \\
\text { and Time }\end{array}$ & Summary of K Effects on Potato Tuber Quality & References \\
\hline $\begin{array}{c}\text { Manitoba, Canada; } \\
\text { 2006-2008 }\end{array}$ & 164 & $\begin{array}{l}\text { 5.8-6.5; Sandy } \\
\text { loam, Loam, Loamy } \\
\text { sand, Loamclay } \\
\text { Loam; } 1.9-3.5\end{array}$ & $\mathrm{KCl}$ & 31-250; Split applied & $\begin{array}{l}\text { Results demonstrated the reduction in specific } \\
\text { gravity with } \mathrm{KCl} \text { application. }\end{array}$ & Mohr and Tomasiewicz [33] \\
\hline $\begin{array}{l}\text { Inner Mongolia, Gansu, } \\
\text { Qinghai and Ningxia } \\
\text { Provinces, China; 2003-2013 }\end{array}$ & 122.2 & $\begin{array}{l}\text { 8.2; Sandy loam, loam, clay } \\
\text { loam; } 0.8\end{array}$ & $\mathrm{KCl}$ & 90; Before planting & $\begin{array}{l}\text { Application of } \mathrm{KCl} \text { increased mean tuber weight, } \\
0.4 \% \text { tuber starch content and reduced } 0.2 \% \\
\text { tuber sugar content compared to control. } \\
\text { Results indicated that dry matter and specific }\end{array}$ & Li et al. [25] \\
\hline $\begin{array}{l}\text { Islamabad, Pakistan; } \\
\text { 2005-2006 }\end{array}$ & 82 & 8.2; Coarse loamy; 0.86 & $\mathrm{~K}_{2} \mathrm{SO}_{4} \mathrm{KCl}$ & 150 and 225; Before planting & $\begin{array}{l}\text { gravity were more affected by } \mathrm{K}_{2} \mathrm{SO}_{4} \text { than } \mathrm{KCl} \text {. } \\
\text { Moreover, specific gravity, dry matter, vitamin } \mathrm{C} \text {, } \\
\text { starch contents, chips color and taste were } \\
\text { improved with two sources of } \mathrm{K} \text {. }\end{array}$ & Khan et al. [24] \\
\hline $\begin{array}{l}\text { Washington, USA; } \\
\text { 1997-1999 }\end{array}$ & $\begin{array}{l}135 \\
154 \\
86\end{array}$ & ND & $\mathrm{K}_{2} \mathrm{SO}_{4} \mathrm{KCl}$ & $\begin{array}{l}\text { 392, } 364 \text { and } 448 ; \\
\text { Before planting and in-season }\end{array}$ & $\begin{array}{l}\text { The results of this study strongly claimed that } \mathrm{K} \\
\text { source does not affect tuber specific gravity. }\end{array}$ & Davenport and Bentley [37] \\
\hline $\begin{array}{l}\text { Wadi Addawasir } \\
\text { region-Saudi Arabia; } \\
\text { 2000-2002 }\end{array}$ & $\begin{array}{l}215 \\
278\end{array}$ & 7.4-7.9; Loamy sand; ND & $\mathrm{K}_{2} \mathrm{SO}_{4}$ & 25-100; Before planting & $\begin{array}{l}\text { Results showed that there were no statistical } \\
\text { differences between the levels of K on specific } \\
\text { gravity and frying quality. }\end{array}$ & AbdelGadir et al. [72] \\
\hline $\begin{array}{l}\text { Utah, USA; } \\
\text { 1988-1989 }\end{array}$ & $\begin{array}{l}59 \\
77\end{array}$ & 7.7-7.9; Silt loam; 1.2 & $\mathrm{~K}_{2} \mathrm{SO}_{4} \mathrm{KCl}$ & 112-448; Before planting & $\begin{array}{l}\text { Both K sources decreased specific gravity. Also, } \\
\text { this study showed that } \mathrm{N} \text { or K fertilizers can be } \\
\text { applied according to their respective soil test } \\
\text { concentration and the crop's requirement, } \\
\text { generally without consideration of K sources. }\end{array}$ & Westermann et al. [69] \\
\hline
\end{tabular}

$\mathrm{K}_{2} \mathrm{SO}_{4}$ (potassium sulfate); $\mathrm{KCl}$ (potassium chloride); $\mathrm{ND}$ (not defined). 


\section{Potassium Source and Rate on Potatoes}

There is little information on the critical soil $\mathrm{K}$ levels for high potato tuber yield and quality; the challenge of determining the correct $\mathrm{K}$ fertilizer rate and the source is persistent [25]. In the following sections, we attempt to explain the aspects of $\mathrm{K}$ fertilizer source and rate in potato production as they influence tuber yield and quality.

\subsection{Effects of $K$ Source}

In Figure 5, we have summarized data from 48 peer-reviewed studies on the effects of $\mathrm{K}$ on potato tuber yield from various sources, including potassium sulfate $\left(\mathrm{K}_{2} \mathrm{SO}_{4}\right)$, potassium chloride $(\mathrm{KCl})$ and potassium nitrate $\left(\mathrm{KNO}_{3}\right)$, regardless of exchangeable soil $\mathrm{K}$ levels. Among these three types of fertilizers, $\mathrm{KCl}$ and $\mathrm{K}_{2} \mathrm{SO}_{4}$ were superior to $\mathrm{KNO}_{3}$ in increasing tuber production and a positive effect of $\mathrm{K}_{2} \mathrm{SO}_{4}$ was reported on the number of tubers [77]. A field study that was conducted in Wisconsin indicated that $\mathrm{K}_{2} \mathrm{SO}_{4}$ application tended to enhance yields more than $\mathrm{KCl}$ at rates up to $280 \mathrm{~kg} \mathrm{~K}$ ha $^{-1}$, when the $\mathrm{K}$ soil test ranged from 75 to $110 \mathrm{mg} \mathrm{kg}^{-1}$ [40]. By contrast, other studies showed that effects of $\mathrm{KCl}$ were similar to or better than those of $\mathrm{K}_{2} \mathrm{SO}_{4}$ on potato yield and quality [24,37,53]. It is presumed that $\mathrm{KCl}$ fertilization leads to a higher plant osmotic potential, compared to $\mathrm{K}_{2} \mathrm{SO}_{4}$, resulting in greater water uptake and vegetative growth, and an increase in competition for assimilates between shoot and tuber, as the shoot is a strong sink for assimilates [78].

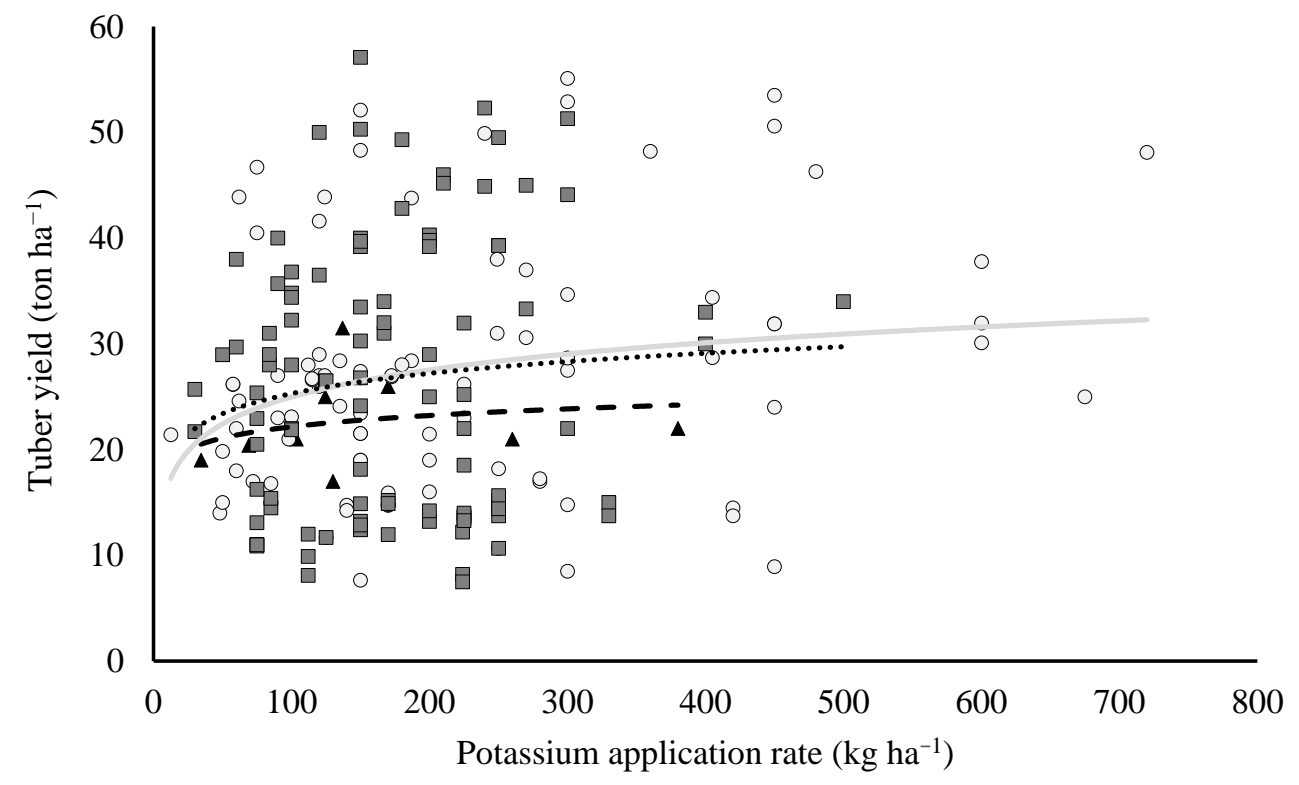

\footnotetext{
\ Potassium nitrate

- - - Potassium nitrate
}

- Potassium sulfate

$\square \quad$ Potassium chloride Potassium sulfate Potassium chloride

Figure 5. Tuber yield of potato in response to varying application rates and sources of potassium fertilizers. (Some data used here are sourced from Supplementary Materials).

Sharma and Sud [79] conducted studies on acidic and alluvial soils and showed that $\mathrm{K}_{2} \mathrm{SO}_{4}$ was superior to $\mathrm{KCl}$ in increasing tuber dry matter, ascorbic acid, and starch content. Indeed, $\mathrm{K}_{2} \mathrm{SO}_{4}$ is a readily plant-available form of $\mathrm{K}$ [80] and this could explain the faster translocation of photosynthates from leaves and stems to tubers under fertilization with $\mathrm{K}_{2} \mathrm{SO}_{4}$ compared to $\mathrm{KCl}$ [69]. Furthermore, Kumar et al. [49] reported an increased percentage dry matter following fertilization with $\mathrm{K}_{2} \mathrm{SO}_{4}$ compared to $\mathrm{KCl}$, while Perrenoud [71] observed decreased percentage dry matter, which was attributed to chloride ions following fertilization with $\mathrm{KCl}$. Generally, it seems that $\mathrm{K}$ applied as $\mathrm{KCl}$ above the recommended rate has more negative effects on dry matter percentage than $\mathrm{K}_{2} \mathrm{SO}_{4}$ [69]. This difference 
is largely due to the presence of chloride ions in the soil solution [81]. Manolov et al. [82], in both greenhouse pot experiments and field studies, reported that starch content was higher following $\mathrm{K}_{2} \mathrm{SO}_{4}$ treatment, compared to $\mathrm{KCl}$ when equal rates of $\mathrm{K}$ were applied. However, Khan et al. [24] indicated that starch content was unaffected by $\mathrm{KCl}$ application. They indicated that $\mathrm{KCl}$ application improved chipping quality of tubers relative to $\mathrm{K}_{2} \mathrm{SO}_{4}$, because it decreased enzymatic discoloration and phenol content of tubers. Despite $\mathrm{KCl}$ and $\mathrm{K}_{2} \mathrm{SO}_{4}$ being the most popular $\mathrm{K}$ fertilizers used in potato production, occasionally, other types are also used. In a field study under semi-arid conditions and a loamy sand soil, and the foliar application of $\mathrm{KNO}_{3}$ did not increase tuber yield and number of tubers despite the significant increase in plant height [83].

However, a recent study in Egypt showed that potassium silicate $\left(\mathrm{K}_{2} \mathrm{Si}_{2} \mathrm{O}_{5}\right)$, a source of both $\mathrm{K}$ and highly soluble silicon, promoted vegetative growth, yield components and N, $\mathrm{P}$, $\mathrm{K}$ concentrations of potato plants, irrigated with saline water [84]. This was attributed to the beneficial effect of silicon in increasing plant resistance to biotic and abiotic stress [85]. In a study with foliar spray of $\mathrm{KNO}_{3}, \mathrm{~K}_{2} \mathrm{SiO}_{3}, \mathrm{KCl}$ and mono potassium phosphate $\left(\mathrm{KH}_{2} \mathrm{PO}_{4}\right)$, Salim et al. [86] observed the highest tuber yield in $\mathrm{K}_{2} \mathrm{SiO}_{3}$. A new $\mathrm{K}$ fertilizer, potassium phosphite $\left(\mathrm{K}_{3} \mathrm{O}_{3} \mathrm{P}\right)$ which was treated to seed tubers followed by foliage application, was reported to have a benefit of protecting the tuber from pathogen attack, dehydration, and wounding during harvest and storage [87]. Recently, another $\mathrm{K}$ fertilizer, polyhalite $\left[\mathrm{K}_{2} \mathrm{Ca}_{2} \mathrm{Mg}\left(\mathrm{SO}_{4}\right) 4 \cdot 2 \mathrm{H}_{2} \mathrm{O}\right]$ showed positive effects on tuber skin appearance, although it may be dependent on local conditions and potato cultivar type [88].

Based on the existing literature, it is believed that the source of $K$ has a significant effect on tuber yield and quality, and this should be taken into consideration according to the final market goal of the producer.

\subsection{Effects of K Rate}

As illustrated in Figure 5, tuber yield responded better to application rates of up to $200 \mathrm{~kg} \mathrm{ha}^{-1}$ when $\mathrm{K}_{2} \mathrm{SO}_{4}$ or $\mathrm{KCl}$ were applied, whereas fertilization with either compound did not result in marked tuber yield increases. However, for $\mathrm{KNO}_{3}$, noticeable increases in tuber yield were recorded at fertilization rates less than $100 \mathrm{~kg} \mathrm{ha}^{-1}$. In this regard, the optimum application rate was $<225 \mathrm{~kg} \mathrm{ha}^{-1}$ (as $\mathrm{K}_{2} \mathrm{O}$, source not defined) on low-K soils (76 mg kg ${ }^{-1}$ ) [68]. Abdelgadir et al. [72] found that an application of $215 \mathrm{~kg} \mathrm{~K}_{2} \mathrm{O}$ ha ${ }^{-1}$ was adequate to optimize economic yield and specific gravity, while minimizing fried chip defects. Nonetheless, rates higher than those reported by Abdelgadir et al. [72] are commonly applied by potato farmers/producers. Furthermore, Job et al. [89] reported that the maximum tuber yield was obtained with an estimated fertilization rate of $325 \mathrm{~kg}$ of $\mathrm{K}_{2} \mathrm{O} \mathrm{ha}{ }^{-1}$ in a soil with low exchangeable $\mathrm{K}\left(27 \mathrm{mg} \mathrm{kg}^{-1}\right)$, while the tuber yield increased only up to the rate of $200 \mathrm{~kg} \mathrm{~K}_{2} \mathrm{O} \mathrm{ha}^{-1}$ in the soils with 62 and $144 \mathrm{mg} \mathrm{kg}^{-1}$ exchangeable soil $\mathrm{K}$. In this regard, several researchers revealed that most vegetative parameters, as well as yield and its components, increased significantly when $\mathrm{K}$ fertilization rates increased from 120 to $240 \mathrm{~kg} \mathrm{~K}_{2} \mathrm{O} \mathrm{ha}^{-1}$ [28,64]. Singh and Singh [90] observed a noteworthy increase in plant height and shoot biomass of potato as $\mathrm{K}$ fertilization rates increased from 50 to $200 \mathrm{~kg} \mathrm{~K}_{2} \mathrm{O} \mathrm{ha}^{-1}$.

The scientific reports about $\mathrm{K}$ fertilizer impact on potato yield are controversial, indicating no or low crop response to high application rates [25]. Supportively, K treatments do not always increase potato yield [91,92], mainly because the plants are unresponsive to the increased abundance of $\mathrm{K}$ in the soil. Indeed, increase of $\mathrm{K}$ rate did not affect crop yield due to the variety's response to $\mathrm{K}$ fertilizer and location and growing, soil and climatic conditions [93]. Asmaa and Hafez [94] found that growth parameters of potato gradually increased as rates of $\mathrm{K}$ fertilization increased from 100 to $300 \mathrm{~kg} \mathrm{~K}_{2} \mathrm{O} \mathrm{ha}{ }^{-1}$. Singh and Lal [64] conducted a study to determine the optimum $\mathrm{K}$ fertilization rate for maximum yield, nutrient use efficiency and quality of potato under irrigation on a sandy loam soil with $179 \mathrm{mg} \mathrm{kg}^{-1}$ exchangeable soil K content. Tuber yield, in the form of increased large and medium tubers and decreased small $(<25 \mathrm{~g})$ tubers, was directly increased 
by increasing $\mathrm{K}$ application rate. Maximum yield (33.5 ton ha ${ }^{-1}$ ) was reached with the application of $150 \mathrm{~kg} \mathrm{~K} \mathrm{ha}^{-1}$, while minimum tuber yield $\left(22.2\right.$ ton ha $\left.{ }^{-1}\right)$ was obtained in no $\mathrm{K}$ application treatment [64]. An increase in yield of tubers from four genotypes due to $\mathrm{K}$ application up to $150 \mathrm{~kg} \mathrm{~K}_{2} \mathrm{O} \mathrm{ha}^{-1}$ was observed on an irrigated sandy loam soil with available $\mathrm{K}$ content $75 \mathrm{mg} \mathrm{kg}^{-1}$ [38].

According to Karam et al. [23], $\mathrm{K}$ fertilizer applications of 75 and $150 \mathrm{~kg} \mathrm{~K}_{2} \mathrm{O}$ ha ${ }^{-1}$ significantly increased potato yield, and reached a plateau, thereafter, showing luxury consumption of the nutrient at $225 \mathrm{~kg} \mathrm{~K}_{2} \mathrm{O}$ ha $^{-1}$. Interestingly, Zelelw et al. [95] reported that $150 \mathrm{~kg} \mathrm{~K}_{2} \mathrm{O} \mathrm{ha}^{-1}$ might be an excessive rate that causes decline in tuber production; this effect depends on the variety. They claim that a high rate of $\mathrm{K}$ potentially could compete with exchangeable $\mathrm{Mg}$ and may cause $\mathrm{Mg}$ deficiency, which finally results in a reduction in tuber yield [73]. By contrast, studies showed that application rates between 214 and $393 \mathrm{~kg} \mathrm{~K}_{2} \mathrm{O} \mathrm{ha}^{-1}$ are required to maximize total tuber yield under tropical soils of Brazil with low initial exchangeable $\mathrm{K}$ concentration $\left(<100 \mathrm{mg} \mathrm{kg}^{-1}\right)$ [35]. However, based on Perrenoud [71], $\mathrm{K}$ amount required to produce 1 ton of potato tubers is $5.2 \mathrm{~kg} \mathrm{~K} 2 \mathrm{O}$. Luxury consumption of $\mathrm{K}$ could explain this discrepancy [39,96], the increase of potato biomass and tuber yield stop at a certain external $\mathrm{K}$ level, even though the plants continue to take up K.

\section{Application Method}

The potato plant shows maximum uptake of $\mathrm{K}$, early in plant development, approximately 30 to 40 days after emergence, afterwards, the uptake of $\mathrm{K}$ drops close to zero during the maturity phase of the tubers $[97,98]$. In this regard, pre-plant applications can largely fulfill the fertilizer requirements during plants' vegetative and reproductive stages, which generally is more cost effective. Although pre-plant fertilization is usually more effective, $\mathrm{K}$ broadcasting as band application might lead to salt stress [97]. Another type of $\mathrm{K}$ fertilization is split, which might be an efficient strategy to optimize tuber yield [99]. Supporting that suggestion, Singh et al. [90] indicated that a split K application is superior to a full application of K at planting. However, Kumar et al. [49] observed that application methods (basal dressing, split and split application + foliar spray) had no significant effect on processing grade and total tuber yield or on tuber-specific gravity and dry-matter percentage. Furthermore, Mohr [33] observed that $\mathrm{KCl}$ pre-plant vs. hilling application or split application had no consistent effect on marketable and total yield, leading them to suggest pre-plant application as a reliable management practice. These findings agree with previous studies, which have reported no yield benefit to split or in-season application of K fertilizer compared with pre-plant application $[37,100]$.

\section{Concerns on K Recommendation}

Soil testing is a common method in determining $\mathrm{K}$ recommendations and can be effective in guiding fertilizer applications [74]. Soil nutrient analysis is a beneficial tool to estimate soil $\mathrm{K}$ content and accordingly direct nutrient management in potato production $[28,45]$. Traditionally, fertilization is adjusted based on the concentration of exchangeable soil K [92,100]. However, soil analysis does not indicate the diffusion and adsorption of soil $\mathrm{K}$ as it interacts with other nutrients on soil exchange sites [25]. The diffusion of $\mathrm{K}$ to roots depends on root characteristics such as length, surface area, and mass of the potato root system [101]. Poor correlations between tuber yields and $\mathrm{K}$ fertilization [33,41], or between tuber yield and the initial levels of exchangeable $\mathrm{K}$ in soil convinced researchers to consider several factors for suitable $\mathrm{K}$ fertilization recommendation, such as water availability and $\mathrm{K}$ interactions with other nutrients [25].

Since soil analysis does not consider the climatic and plant factors [102], thus, plant tissue analysis as an efficient method of monitoring nutritional status of a crop could be regarded, which can calibrate fertilizer requirements of potato crops. Additionally, during the growing season, potential deficiencies can be detected for treatments of any nutrient disorders [103]. Almost every portion of the potato plant has been used to evaluate 
nutritional status, including leaflets, petioles, whole leaves, stems, roots, tubers and others dismembered plant parts [102]. The petiole is the commonly selected plant part for use in potato nutritional analysis, although it may not be the most appropriate for all nutrients or in all situations [104]. Dow [105] demonstrated that petioles is more sensitive to changes in macronutrient concentration of soil. Walworth and Muniz [104] reported that adequate K concentration in petioles for the potato in half-grown to maturity is $>60 \mathrm{~g} \mathrm{~K} \mathrm{~kg}^{-1}$. Sharma and Arora [103] suggested 81-85, 77-85, and 71-76 $\mathrm{g} \mathrm{K} \mathrm{kg}^{-1}$ in petioles at 30, 45 and 60 days after plant emergence, respectively. It should be noted that the $\mathrm{K}$ concentration varied greatly between young and old leaves. For example, Fontes et al. [106] found that the $\mathrm{K}$ concentration in petioles were $89 \mathrm{~g} \mathrm{~K} \mathrm{~kg}^{-1}$ for youngest fully expanded leaves and $61 \mathrm{~g} \mathrm{~K} \mathrm{~kg}^{-1}$ for oldest, but not senescent leaves. Petiole $\mathrm{K}$ concentration was linearly related to the K concentration in the photosynthetically active leaves, aboveground plant parts and tubers. This demonstrated that $\mathrm{K}$ concentration in the fourth petiole is a suitable indication of the $\mathrm{K}$ status of the plant [107]. It was reported that a $\mathrm{K}$ concentration of $70-75 \mathrm{~g} \mathrm{~K} \mathrm{~kg}^{-1}$ for the fourth petiole of Russet Burbank potatoes was adequate to achieve the optimal potato growth and yield [97].

In general, soil and plant tissue analysis function as interoperable or complementary tools for better assessment of crop nutrient needs and more rational utilization of fertilizers. Soil analysis may provide immediate information on soil fertility before planting. One of the main advantages of plant tissue analysis is the rapid assessment of the nutritional status of the plant at critical stages of development. However, each method is not able to fully cover the nutrient status in both soil and plant. Therefore, both soil analysis and tissue analysis are often conducted regularly for providing timely information for growers to decide on a fertilization plan to achieve an optimal yield target.

Recommendations for $\mathrm{K}$ fertilization are principally based on $\mathrm{K}$ balance in the soilplant system, while alternatively, they may be based on the amount of K removed by crop and have successfully been used for wheat and maize [108]. A similar strategy can be applied on $\mathrm{K}$ fertilization recommendation by considering the amount of $\mathrm{K}$ removed by the tubers. Conversely, some researchers question $\mathrm{K}$ fertilization recommendations based on the requirement of tubers because of luxury uptake [41,92]. In this regard, an increase in $\mathrm{K}$ removal by the tubers would be higher than the tuber yield increase attributed to the K luxury consumption by the crop [92]. Potato has multiple uses such as fresh market, processing (French fries, chips, etc.), industrial use (dehydrated, starch, alcohol, etc.), and seed, etc. Different uses are associated with the potato varieties, which shows different potassium use efficiency. Ideally, the potato variety should be considered in deciding $\mathrm{K}$ fertilization strategy. Therefore, an accurate estimation and a valid $\mathrm{K}$ fertilizer schedule should be based on factors such as the soil exchangeable $K$, the amount of $\mathrm{K}$ removal by the crop, and the type of variety.

\section{Future Perspective}

Through modeling the data from the existing literature, an attempt is made to understand the role of soil $\mathrm{K}$ and $\mathrm{K}$ fertilization on potato yield and quality. A similar approach or meta-analysis may be applied to evaluate $\mathrm{K}$ fertilization in the potato production system. Although $\mathrm{pH}$, texture, and organic matter of soil have been considered in the paper, more factors such as climate, potato variety, crop rotation, irrigation, soil health, other fertilizer sources (i.e., organic manure, bio-fertilizer), pest control practices, soilborne diseases, pests, and weeds should be evaluated in understanding $\mathrm{K}$ management for potatoes. Moreover, it is necessary to assess the potential of $\mathrm{K}$ uptake in different potato varieties through a series of systematic studies to investigate the interaction of various biotic and abiotic factors and $\mathrm{K}$ application on yield, and quality of tubers including size, specific gravity, nutrition component, and storage life.

Prioritization of $\mathrm{K}$ management studies is improving $\mathrm{K}$ use efficiency, which could be achieved through breeding new varieties, improving fertilization methods, and applying new fertilizers along with the reduction of $\mathrm{K}$ consumption or increase of tuber production. 
New varieties having efficient root systems in K uptake could be considered by researchers through marker-assisted technology. Fertilization by following the $4 \mathrm{R}$ nutrient stewardship approach of selecting the right source at the right rate at the right time and in the right place is important for achieving the yield and quality target and reducing the risk of nutrient loss. The development of decision support tools for site-specific $\mathrm{K}$ fertilizer recommendations will show the great potential in K management. Moreover, the application of economicavailable slow-release fertilizers to match the potato $\mathrm{K}$ uptake could be regarded as well.

It is believed that slowly available $\mathrm{K}$ and mineral $\mathrm{K}$ may be utilized by plants, besides the water-soluble K and the exchangeable K [109]. However, the methods on detecting the slow-available $\mathrm{K}$ and mineral $\mathrm{K}$ which could be utilized by crops in season are still lacking. Although the $\mathrm{K}$ dynamic among the different $\mathrm{K}$ forms in soils is well known, there are still knowledge gaps that need to be addressed to understand and quantify the transformation among the different forms [110]. Particularly, the involvement of crops may make the K dynamics become more complicated. Additionally, studies should be conducted to evaluate the fate of applied $\mathrm{K}$ in the soil, a portion of which might be fixed or even lost as leaching, although the applied $\mathrm{K}$ commonly is thought to be fully utilized by crops. Meanwhile, the K dynamics induced by K fertilization are still not clear.

\section{Conclusions}

This review based on the modeling results showed that the highest tuber yield approximates at exchangeable soil $\mathrm{K}^{+}$concentration of $200 \mathrm{mg} \mathrm{kg}^{-1}$, regardless of texture, $\mathrm{pH}$, and organic matter content of soils. For soils with higher $\mathrm{K}$ content, it might be difficult to expect the potato yield response to $\mathrm{K}$ fertilizer. The optimum application rates for obtaining the highest tuber yield were approximately $200 \mathrm{~kg} \mathrm{ha}^{-1}$ for $\mathrm{K}_{2} \mathrm{SO}_{4}$ and $\mathrm{KCl}$, and $100 \mathrm{~kg}$ $\mathrm{ha}^{-1}$ for $\mathrm{KNO}_{3}$. Although there are some studies that have shown the efficacy of split applications of $\mathrm{K}$ fertilizer, pre-plant fertilization might be still a reliable management practice. However, it should be noted that the soil $\mathrm{K}$ content and the rates of $\mathrm{K}$ fertilizers might not be applicable for every scenario because of the varied environmental conditions and different potato varieties, etc.

As a common strategy for proper $\mathrm{K}$ fertilizer rate determination, soil exchangeable $\mathrm{K}$ should be one of the most important factors to be considered in deciding a fertilization plan before crop season. Plant tissue analysis reflects the level of nutritional status of the plant and may help growers making decisions on seasonal fertilization. Particularly, a combination of soil analysis and tissue analysis, plus potato cultivars and yield potential, may provide a better basis for $\mathrm{K}$ fertilization recommendations. Additionally, soil physical and chemical characteristics, cropping system, climatic conditions, and growing season should be considered.

Supplementary Materials: The following are available online at https:/ / www.mdpi.com/2073-439 5/11/3/543/s1. Listed references that some data come from were for modeling regression in the figures of the paper.

Author Contributions: All authors contributed substantially to the work reported in this paper. Conceptualization, S.T., R.Q.; methodology, S.T., S.F.-A.; data curation, S.T., S.F.-A., R.Q., C.N.; writing-original draft preparation, S.T., S.F.-A.; writing-review and editing, S.T., S.F.-A., R.Q., C.N., V.S., B.C. and D.A.L. All authors have read and agreed to the published version of the manuscript.

Funding: This research received no external funding.

Conflicts of Interest: The authors declare no conflict of interest.

\section{References}

1. FAOSTAT. 2018. Available online: http:/ / www.fao.org/faostat/en (accessed on 8 March 2018).

2. Rajiv Kawar, P.G. Enriched Potato for Mitigating Hidden Hunger. In Biofortification of Food Crops; Springer: New Delhi, India, 2016; pp. 433-457.

3. Larkin, R.P. Incorporating soil health management practices into viable potato cropping systems. In Proceedings of the Northeast Potato Technology Forum Conspectus, Fredericton, NB, Canada, 15-16 March 2017; pp. 46-47. 
4. Navarre, R.; Pavek, M.J. The Potato: Botany, Production and Uses; CABI: Boston, MA, USA, 2014.

5. Zaheer, K.; Akhtar, M.H. Potato production, usage, and nutrition-A review. Crit. Rev. Food Sci. Nutr. 2016, 56, 711-721. [CrossRef] [PubMed]

6. Camire, M.E.; Kubow, S.; Donnelly, D.J. Potatoes and human health. Crit. Rev. Food Sci. Nutr. 2009, 49, 823-840. [CrossRef]

7. Ezekiel, R.; Singh, N.; Sharma, S.; Kaur, A. Beneficial phytochemicals in potato-A review. Food Res. Int. 2013, 50, 487-496. [CrossRef]

8. Rytel, E.; Lisińska, G.; Tajner-Czopek, A. Toxic compound levels in potatoes are dependent on cultivation methods. Acta Aliment. 2013, 42, 308-317. [CrossRef]

9. Czajkowski, R.; Perombelon, M.C.; van Veen, J.A.; van der Wolf, J.M. Control of blackleg and tuber soft rot of potato caused by Pectobacterium and Dickeya species: A review. Plant Pathol. 2011, 60, 999-1013. [CrossRef]

10. Delleman, J.; Mulder, A.; Turkensteen, L.J. Potato Diseases. Diseases, Pests and Defects; NIVAP: De Haag, The Netherlands, 2005; p. 280.

11. Harris, P.M. Mineral Nutrition. In The Potato Crop; Springer: Dordrecht, The Netherlands, $1992 ;$ pp. $162-213$.

12. Oosterhuis, D.M.; Loka, D.A.; Kawakami, E.M.; Pettigrew, W.T. The physiology of potassium in crop production. Adv. Agron. 2014, 126, 203-233.

13. Anschütz, U.; Becker, D.; Shabala, S. Going beyond nutrition: Regulation of potassium homoeostasis as a common denominator of plant adaptive responses to environment. J. Plant Physiol. 2014, 171, 670-687. [CrossRef]

14. Oddo, E.; Inzerillo, S.; La Bella, F.; Grisafi, F.; Salleo, S.; Nardini, A. Short-term effects of potassium fertilization on the hydraulic conductance of Laurus nobilis L. Tree Physiol. 2011, 31, 131-138. [CrossRef]

15. Jordan-Meille, L.; Pellerin, S. Leaf area establishment of a maize (Zea mays L.) field crop under potassium deficiency. Plant Soil 2004, 265, 75-92. [CrossRef]

16. Song, W.; Xue, R.; Song, Y.; Bi, Y.; Liang, Z.; Meng, L.; Dong, C.; Wang, C.; Liu, G.; Dong, J.; et al. Differential response of first-order lateral root elongation to low potassium involves nitric oxide in two tobacco cultivars. J. Plant Growth Regul. 2018, 37, 114-127. [CrossRef]

17. Hu, W.; Coomer, T.D.; Loka, D.A.; Oosterhuis, D.M.; Zhou, Z. Potassium deficiency affects the carbon-nitrogen balance in cotton leaves. Plant Physiol. Biochem. 2017, 115, 408-417. [CrossRef]

18. Raschke, K. Simultaneous requirement of carbon dioxide and abscisic acid for stomatal closing in Xanthium strumarium L. Planta 1975, 125, 243-259. [CrossRef]

19. Tränkner, M.; Tavakol, E.; Jákli, B. Functioning of potassium and magnesium in photosynthesis, photosynthate translocation and photoprotection. Physiol. Plant 2018, 163, 414-431. [CrossRef] [PubMed]

20. Jákli, B.; Tavakol, E.; Tränkner, M.; Senbayram, M.; Dittert, K. Quantitative limitations to photosynthesis in K deficient sunflower and their implications on water-use efficiency. J. Plant Physiol. 2017, 209, 20-30. [CrossRef]

21. Britzke, D.; Da Silva, L.S.; Moterle, D.F.; dos Santos Rheinheimer, D.; Bortoluzzi, E.C. A study of potassium dynamics and mineralogy in soils from subtropical Brazilian lowlands. J. Soils Sediments 2012, 12, 185-197. [CrossRef]

22. Römheld, V.; Kirkby, E.A. Research on potassium in agriculture: Needs and prospects. Plant soil. 2010, 335, 155-180. [CrossRef]

23. Karam, F.; Massaad, R.; Skaf, S.; Breidy, J.; Rouphael, Y. Potato response to potassium application rates and timing under semi-arid conditions. Adv. Hortic. Sci. 2011, 265-268.

24. Khan, M.Z.; Akhtar, M.E.; Mahmood-ul-Hassan, M.; Mahmood, M.M.; Safdar, M.N. Potato tuber yield and quality as affected by rates and sources of potassium fertilizer. J. Plant Nutr. 2012, 35, 664-677. [CrossRef]

25. Li, S.; Duan, Y.; Guo, T.; Zhang, P.; He, P.; Johnston, A.; Shcherbakov, A. Potassium management in potato production in Northwest region of China. Field Crops Res. 2015, 174, 48-54. [CrossRef]

26. Mengel, K.; Kirkby, E.A. Principles of Plant Nutrition; Kluwer Academic Publishers; Springer: Dordrecht, The Netherlands, 2001; p. 849.

27. Rosen, C.J.; Errebhi, M.; Wang, W. Testing petiole sap for nitrate and potassium: A comparison of several analytical procedures. HortScience 1996, 31, 1173-1176. [CrossRef]

28. Allison, M.F.; Fowler, J.H.; Allen, E.J. Responses of potato (Solanum tuberosum) to potassium fertilizers. J. Agric. Sci. 2001, 136, 407-426. [CrossRef]

29. Malakouti, M.J.; Mirsolaymani, M.Y. Response of potato to potassium in the calcareous soils of Iran. In Proceedings of the Soil and Water Institute (SWRI) and the International Potash Institute (IPI) on K Availability of Soils of West Asia and North Africa-Status and Perspectives, Tehran, Iran, 19-23 June 1993; pp. 249-260.

30. Grewal, J.S.; Singh, S.N. Effect of potassium nutrition on frost damage and yield of potato plants on alluvial soils of the Punjab (India). Plant Soil. 1980, 57, 105-110. [CrossRef]

31. Sandaña, P.; Orena, S.; Rojas, J.S.; Kalazich, J.; Uribe, M. Critical Value of Soil Potassium for Potato Crops in Volcanic Soils. J. Soil Sci. Plant Nutr. 2020, 20, 1171-1177. [CrossRef]

32. Pauletti, V.; Menarin, E. Timing, sources and rates of potassium fertilizer application for potato. Sci. Agrar. 2004, 5, 15-20.

33. Mohr, R.M.; Tomasiewicz, D.J. Effect of rate and timing of potassium chloride application on the yield and quality of potato (Solanum tuberosum L. 'Russet Burbank'). Can. J. Plant Sci. 2012, 92, 783-794. [CrossRef]

34. Haile, W. Response of Irish potato (Solanum tuberosum) to the application of potassium at acidic soils of Chencha, Southern Ethiopia. Int. J. Agric. Biol. 2011, 13, 595-598. 
35. Silva, H.R.F.; Fontes, P.C.R. Potassium fertilization and its residual effect on productivity and quality of potato tubers. Pesqui Agropecu Bras. 2016, 51, 842-848. [CrossRef]

36. da Costa Mello, S.; Pierce, F.J.; Tonhati, R.; Almeida, G.S.; Neto, D.D.; Pavuluri, K. Potato response to polyhalite as a potassium source fertilizer in Brazil: Yield and quality. HortScience 2018, 53, 373-379. [CrossRef]

37. Davenport, J.R.; Bentley, E.M. Does potassium fertilizer form, source, and time of application influence potato yield and quality in the Columbia Basin? Am. Potato J. 2001, 78, 311-318. [CrossRef]

38. Moinuddin, S.K.; Bansal, S.K. Growth, yield, and economics of potato in relation to progressive application of potassium fertilizer. J. Plant Nutr. 2005, 28, 183-200. [CrossRef]

39. Karam, F.; Rouphael, Y.; Lahoud, R.; Breidi, J.; Colla, G. Influence of genotypes and potassium application rates on yield and potassium use efficiency of potato. J. Agron. 2009, 8, 27-32. [CrossRef]

40. Panique, E.; Kelling, K.A.; Schulte, E.E.; Hero, D.E.; Stevenson, W.R.; James, R.V. Potassium rate and source effects on potato yield, quality, and disease interaction. Am. Potato J. 1997, 74, 379-398. [CrossRef]

41. Shi, X.; Zhang, X.; Kang, W.; Chen, Y.; Fan, M. Possibility of recommending potassium application rates based on a rapid detection of the potato petiole K status with a portable K ion meter. Am. Potato J. 2019, 96, 48-54. [CrossRef]

42. Malvi, U.R. Interaction of micronutrients with major nutrients with special reference to potassium. Karnataka J. Agric. Sci. 2011, 24, 106-109.

43. Bishwoyog, B.; Swarnima, K.C. Effect of potassium on quality and yield of potato tubers-A review. SSRG-IJAES 2016, 3, 9-14.

44. Schilling, G.; Eißner, H.; Schmidt, L.; Peiter, E. Yield formation of five crop species under water shortage and differential potassium supply. J. Soil Sci. Plant Nutr. 2016, 179, 234-243. [CrossRef]

45. Soratto, R.P.; Job, A.L.; Fernandes, A.M.; Assunção, N.S.; Fernandes, F.M. Biomass accumulation and nutritional requirements of potato as affected by potassium supply. J. Soil Sci. Plant Nutr. 2020, 20, 1051-1066. [CrossRef]

46. Zhang, W.; Liu, X.; Wang, Q.; Zhang, H.; Li, M.; Song, B.; Zhao, Z. Effects of potassium fertilization on potato starch physicochemical properties. Int. J. Biol. Macromol. 2018, 117, 467-472. [CrossRef] [PubMed]

47. Bogucka, B.; Elżbieta, T. Effect of nitrogen and potassium fertilization on mineral and amino acid content of colored flesh potato cultivar Blue Congo. J. Plant Nutr. 2018, 41, 856-866. [CrossRef]

48. Shunka, E.; Chindi, A.; Gebremedhin, W.G.; Seid, E.; Tessema, L. Determination of optimum nitrogen and potassium levels for potato production in central high lands of Ethiopia. Open Agric. 2017, 2, 189-194. [CrossRef]

49. Kumar, P.; Pandey, S.K.; Singh, B.P.; Singh, S.V.; Kumar, D. Influence of source and time of potassium application on potato growth, yield, economics and crisp quality. Potato Res. 2007, 50,1-13. [CrossRef]

50. Abd El-Latif, K.M.; Osman, E.A.M.; Abdullah, R.; Abd El-Kader, N. Response of potato plants to potassium fertilizer rates and soil moisture deficit. Adv. Appl. Sci. Res. 2011, 2, 388-397.

51. Trehan, S.P.; Roy, S.K.; Sharma, R.C. Potato variety differences in nutrient deficiency symptoms and responses to NPK. Better Crops Int. Potash Phosphate Inst. Can. (PPIC) 2001, 15, 18-21.

52. Al-Moshileh, A.M.; Errebi, M.A. November. Effect of various potassium sulfate rates on growth, yield and quality of potato grown under sandy soil and arid conditions. In Proceedings of the IPI Regional Workshop on Potassium and Fertigation Development in West Asia and North Africa, Rabat, Morocco, 24-28 November 2004; pp. 24-28.

53. Khan, M.Z.; Akhtar, M.E.; Safdar, M.N.; Mahmood, M.M.; Ahmad, S.; Ahmed, N. Effect of source and level of potash on yield and quality of potato tubers. Pak. J. Bot. 2010, 42, 3137-3145.

54. Lakshmi, D.V.; Padmaja, G.; Rao, R.C. Effect of levels of nitrogen and potassium on soil available nutrient status and yield of potato (Solanum tuberosum L.). Indian J. Agric. Res. 2012, 46, 36-41.

55. El-Gamal, A.M. Effect of potassium level on potato yield and quality. J. Agric. Sci. Mansoura Univ. 1985, 10, 1473-1476.

56. Humadi, F.M. Influence of potassium rates on growth and yield of potato. Iraq J. Agric. Sci. Zanco (Iraq) 1986, 4, 69-75.

57. Malik, G.C.; Ghosh, D.C. Effect of fertility level, plant density and variety on growth and productivity of potato. Potato Glob. Res. Dev. 2002, 2, 866-871.

58. Chapman, K.S.R.; Sparrow, L.A.; Hardman, P.R.; Wright, D.N.; Thorp, J.R.A. Potassium nutrition of Kennebec and Russet Burbank potatoes in Tasmania: Effect of soil and fertiliser potassium on yield, petiole and tuber potassium concentrations, and tuber quality. Aust. J. Exp. Agric. 1992, 32, 521-527. [CrossRef]

59. Kolbe, H.; Müller, K.; Olteanu, G.; Gorea, T. Effects of nitrogen, phosphorus and potassium fertilizer treatments on weight loss and changes in chemical composition of potato tubers stored at 4 C. Potato Res. 1995, 38, 97-107. [CrossRef]

60. Nandekar, D.N. Effect of seedling tuber size and fertilizer levels on growth, yield and economics of potato production. Potato J. 2005, 32, 71-73.

61. Tawfik, A.A. Potassium and calcium nutrition improves potato production in drip-irrigated sandy soil. Afr. Crop Sci. J. 2001, 9, 147-155. [CrossRef]

62. Adhikari, B.H.; Karki, K.B. Effect of potassium on potato tuber production in acid soils of Malepatan, Pokhara. J. Nep. Agric. Res. 2006, 7, 42-48. [CrossRef]

63. Westermann, D.T. Nutritional requirements of potatoes. Am. Potato J. 2005, 82, 301-307. [CrossRef]

64. Singh, S.K.; Lal, S.S. Effect of potassium nutrition on potato yield, quality and nutrient use efficiency under varied levels of nitrogen application. Potato J. 2012, 39, 155-165.

65. Storey, R.M.J.; Davies, H.V. Tuber quality. In The Potato Crop; Springer: Dordrecht, The Netherlands, 1992; pp. 507-569. 
66. Olanya, O.M.; Larkin, R.P.; Halloran, J.M.; He, Z. Relationships of crop and soil management systems to meteorological variables and potato diseases on a Russet Burbank cultivar. J. Agric. Meteorol. 2014, 70, 91-104. [CrossRef]

67. Zörb, C.; Senbayram, M.; Peiter, E. Potassium in agriculture-status and perspectives. J. Plant Physiol. 2014, 171, 656-669. [CrossRef] [PubMed]

68. Kavvadias, V.; Paschalidis, C.; Akrivos, G.; Petropoulos, D. Nitrogen and potassium fertilization responses of potato (Solanum tuberosum) cv. Spunta. Commun. Soil Sci. Plant Anal. 2012, 43, 176-189. [CrossRef]

69. Westermann, D.T.; Tindall, T.A.; James, D.W.; Hurst, R.L. Nitrogen and potassium fertilization of potatoes: Yield and specific gravity. Am. Potato J. 1994, 71, 417-431. [CrossRef]

70. Quadros, D.A.D.; Iung, M.C.; Ferreira, S.M.R.; Freitas, R.J.S.D. Chemical composition of potato tubers for processing, grown in different levels and sources of potassium. Food Sci. Technol. 2009, 29, 316-323. [CrossRef]

71. Perrenoud, S. Fertilizing for Higher Yield Potato; IPI Bulletin8; International Potash Institute: Berne, Switzerland, 1993.

72. AbdelGadir, A.H.; Errebhi, M.A.; Al-Sarhan, H.M.; Ibrahim, M. The effect of different levels of additional potassium on yield and industrial qualities of potato (Solanum tuberosum L.) in an irrigated arid region. Am. Potato J. 2003, 80, 219-222. [CrossRef]

73. Koch, M.; Busse, M.; Naumann, M.; Jákli, B.; Smit, I.; Cakmak, I.; Hermans, C.; Pawelzik, E. Differential effects of varied potassium and magnesium nutrition on production and partitioning of photoassimilates in potato plants. Physiol. Plant. 2019, 166, 921-935. [CrossRef] [PubMed]

74. Hannan, A.; Arif, M.; Ranjha, A.M.; Abid, A.; Fan, X.H.; Li, Y.C. Using soil potassium adsorption and yield response models to determine potassium fertilizer rates for potato crop on a calcareous soil in Pakistan. Commun. Soil Sci. Plant Anal. 2011, 42, 645-655. [CrossRef]

75. Cummings, G.A.; Wilcox, G.E. Effect of potassium on quality factors-fruits and vegetables. Role Potassium Agric. 1968, $243-267$. [CrossRef]

76. Ebert, G. Potassium nutrition and its effect on quality and post harvest properties of potato. In Proceedings of the International Symposium on Potassium Role and Benefits in Improving Nutrient Management for Food Production, Quality and Reduced Environmental Damages, Orissa, India, 5-7 November 2009; Volume 1, pp. 637-638.

77. Wibowo, C.; Wijaya, K.; Sumartono, G.H.; Pawelzik, E. Effect of potassium level on quality traits of Indonesian potato tubers. Asia Pacific Journal of Sustainable Agriculture. Food Energy 2014, 2, 11-16.

78. Koch, M.; Naumann, M.; Pawelzik, E.; Gransee, A.; Thiel, H. The importance of nutrient management for potato production Part I: Plant nutrition and yield. Potato Res. 2020, 63, 97-119. [CrossRef]

79. Sharma, R.C.; Sud, K.C. Potassium Management for Yield and Quality of Potato; International Potash Institute: Basel, Switzerland, 2001; pp. 363-381.

80. Young, B.K. Potassium Movement and Uptake as Affected by Potassium Source and Placement. Master's Thesis, Auburn University, Auburn, AL, USA, 2009.

81. McDole, R.E. Potassium fertilizer trials with potatoes on coarse-textured soils in southeastern Idaho. Am. Potato J. 1978, 55, 161-170. [CrossRef]

82. Manolov, I.; Neshev, N.; Chalova, V. Tuber quality parameters of potato varieties depend on potassium fertilizer rate and source. Agric. Agric. Sci. Procedia 2016, 10, 63-66. [CrossRef]

83. Dkhil, B.B.; Denden, M.; Aboud, S. Foliar potassium fertilization and its effect on growth, yield and quality of potato grown under loam-sandy soil and semi-arid conditions. Int. J. Agric. Res. 2011, 6, 593-600. [CrossRef]

84. Moussa, S.; Shama, M. Mitigation the adverse effects of irrigation water salinity on potato crop using potassium silicate foliar application. Middle East J. Appl. Sci. 2019, 9, 804-819.

85. Shaaban, M.M.; Abou El-Nour, E.Z.A. Macro and micro-nutrients concentrations and uptake by maize seedlings irrigated with fresh or saline water as affected by K-silicate foliar fertilization. Am. J. Plant Physiol. 2014, 9, 95-102. [CrossRef]

86. Salim, B.B.M.; Abd El-Gawad, H.G.; Abou El-Yazied, A. Effect of foliar spray of different potassium sources on growth, yield and mineral composition of potato (Solanum tuberosum L.). Middle East J. Appl. Sci. 2014, 4, 1197-1204.

87. Lobato, M.C.; Daleo, G.R.; Andreu, A.B.; Olivieri, F.P. Cell wall reinforcement in the potato tuber periderm after crop treatment with potassium phosphite. Potato Res. 2018, 61, 19-29. [CrossRef]

88. Keren-Keiserman, A.; Baghel, R.S.; Fogelman, E.; Faingold, I.; Zig, U.; Yermiyahu, U.; Ginzberg, I. Effects of polyhalite fertilization on skin quality of potato tuber. Front. Plant Sci. 2019, 10, 1379. [CrossRef]

89. Job, A.L.; Soratto, R.P.; Fernandes, A.M.; Assunção, N.S.; Fernandes, F.M.; Yagi, R. Potassium fertilization for fresh market potato production in tropical soils. J. Agron. 2019, 111, 3351-3362. [CrossRef]

90. Singh, V.N.; Singh, S.P. Influence of split application of potassium on qualitative attributes of potato. J. Indian Potato Assoc. 1996, $23,72-74$.

91. Rosen, C.J.; Kelling, K.A.; Stark, J.C.; Porter, G.A. Optimizing phosphorus fertilizer management in potato production. Am. J. Potato Res. 2014, 91, 145-160. [CrossRef]

92. Kang, W.; Fan, M.; Ma, Z.; Shi, X.; Zheng, H. Luxury absorption of potassium by potato plants. Am. J. Potato Res. 2014, 91, 573-578. [CrossRef]

93. Locascio, S.J.; Bartz, J.A.; Weingartner, D.P. Calcium and potassium fertilization of potatoes grown in North Florida I. Effects on potato yield and tissue Ca and K concentrations. Am. Potato J. 1992, 69, 95-104. [CrossRef] 
94. Asmaa, R.M.; Hafez, M.M. Increasing productivity of potato plants (Solanum tubersom L.) by using potassium fertilizer and humic acid application. Int. J. Acad. Res. 2010, 2, 83-88.

95. Zelelew, D.Z.; Ghebreslassie, B.M. Response of potato varieties to potassium levels in Hamelmalo area, Eritrea. J. Plant Stud. 2016, 5. [CrossRef]

96. Trehan, S.P.; Claassen, N. External K requirement of young plants of potato, sugar beet and wheat in flowing solution culture resulting from different internal requirements and uptake efficiency. Potato Res. 1998, 41, 229-237. [CrossRef]

97. Stark, J.C.; Westermann, D.T.; Hopkins, B. Nutrient Management Guidelines for Russet Burbank Potatoes; University of Idaho: Moscow, ID, USA, 2004.

98. Horneck, D.; Rosen, C. Measuring nutrient accumulation rates of potatoes-Tools for better management. Better Crops 2008, 92, 4-6.

99. Chettri, M.; Mondal, S.S.; Roy, B. Influence of potassium and sulphur with or without FYM on growth, productivity and disease index of potato in soils of West Bengal. J. Indian Potato Assoc. 2002, 29, 61-65.

100. Westermann, D.T.; Tindall, T.A. Potassium fertilization of Russet Burbank potatoes. Better Crops Plant Food. 1998, 82, 8-12.

101. Trehan, S.P. Nutrient management by exploiting genetic diversity of potato-A review. Potato J. 2005, 32. [CrossRef]

102. Gupta, A.; Saxena, M.C. Evaluation of leaf analysis as a guide to nitrogen and phosphorus fertilization of potato (Solanum tuberosum L.). Plant Soil 1976, 4, 597-605. [CrossRef]

103. Sharma, U.C.; Arora, B.R. Critical nutrient ranges for potassium in potato leaves and petioles. J. Hortic. Sci. 1989, 64, 47-51. [CrossRef]

104. Walworth, J.L.; Muniz, J.E. A compendium of tissue nutrient concentrations for field-grown potatoes. Am. Potato J. 1993, 70, 579-597. [CrossRef]

105. Dow, A.I. Critical Nutrient Ranges in Northwest Crops; WREP-Western Region Extension Publication-Cooperative Extension Service (USA); Washington State University: Pullman, WA, USA, 1980; Volume 43.

106. Fontes, P.C.R.; Reis, R.A., Jr.; Pereira, P.R.G. Critical potassium concentration and potassium/calcium plus magnesium ratio in potato petioles associated with maximum tuber yields. J. Plant Nutr. 1996, 19, 657-667. [CrossRef]

107. Westermann, D.T.; Tindall, T.A. Potassium diagnostic criteria for potato plants. Better Crops 2000, 84, 6-8.

108. Pettigrew, W.T. Potassium influences on yield and quality production for maize, wheat, soybean and cotton. Physiol. Plant. 2008, 133, 670-681. [CrossRef]

109. Lalitha, M.; Dhakshinamoorthy, M. Forms of soil potassium-A review. Agric. Rev. 2014, 35, 64-68. [CrossRef]

110. Donald, L.; Sparks, D.L. Potassium dynamics in soils. In Advances in Soil Science; Stewart, B.A., Ed.; Springer-Verlag New York Inc.: New York, NY, USA, 1987; Volume 6, pp. 1-62. 